\title{
Perancangan Aplikasi Voice Chat dengan Socket Programming pada Android untuk Jaringan Lokal
}

\author{
Allyza Nanda Purwari ${ }^{1}$, Nugroho Suharto ${ }^{2}$, Abdul Rasyid ${ }^{3}$ \\ ${ }^{1,2}$ Program Studi Jaringan Telekomunikasi Digital, \\ JurusanTeknik Elektro, Politeknik Negeri Malang, Indonesia \\ ${ }^{3}$ Program Studi Teknik Telekomunikasi, \\ JurusanTeknik Elektro, Politeknik Negeri Malang, Indonesia
}

19allyzananda@gmail.com, ${ }^{2}$ nugroho.suharto@polinema.ac.id, ${ }^{3}$ abdul.rasyid@polinema.ac.id

\begin{abstract}
Voice chat application is an application designed to replace the HT function on an Android smartphone. Besides being able to make voice calls, this application can be used to communicate with text. This application does not require cellular networks to communicate, simply by connecting to a network provided by an existing access point. The applications can be used without using a cellular network, when making an application requires a socket. Socket is an API that exists on Android studio software. While socket programming is a way to use socket components to create an application, one of which is a voice chat application. After being installed in android smartphones, each smartphone is connected to a network provided by an existing access point so that it can communicate by voice or text. Communication is carried out between smartphones with one another point to point. The test results can be concluded that this application can be used to communicate with voice and text, as long as the user is on the same network. This application can be used in all types of Android mobile phones for voice communication but communication with text can only be used on certain mobile brands.
\end{abstract}

Keywords - Communication, Operating System, Socket Programming

Abstrak - Aplikasi voice chat merupakan aplikasi yang dirancang untuk menggantikan fungsi HT pada smartphone android. Selain dapat melakukan panggilan dengan suara, aplikasi ini juga dapat digunakan untuk melakukan komunikasi dengan text. Aplikasi ini tidak memerlukan jaringan seluler untuk komunikasi, cukup dengan tersambung pada jaringan yang disediakan oleh access point. Agar aplikasi dapat digunakan tanpa menggunakan jaringan seluler, maka pada saat pembuatan aplikasi memerlukan adanya socket. Socket merupakan komponen/API (Application Programming) yang ada pada software android studio. Sedangkan socket programming merupakan cara untuk menggunakan komponen/API socket untuk membuat sebuah aplikasi salah satunya aplikasi voice chat. Aplikasi yang sudah dibuat nantinya akan diisntall pada beberapa smartphone android. Setelah terinstall, masing-masing smartphone dihubungkan pada jaringan yang disediakan oleh access point yang sudah ada agar dapat melakukan komunikasi dengan suara maupun text. Komunikasi yang dilakuakan antar smartphone satu dengan yang lainnya secara point to point. Hasil pengujian dapat disimpulkan bahwa aplikasi ini dapat digunakan untuk melakukan komunikasi dengan suara maupun text, selama user berada pada jaringan yang sama. Dan juga aplikasi ini dapat digunakan disegala jenis handphone Android untuk melakukan komunikasi dengan suara namun pada komunikasi dengan text hanya bisa digunakan pada merk handphone tertentu saja.

Kata kunci- Komunikasi, Sistem Operasi, Socket Programming

\section{PENDAHULUAN}

Aplikasi voice chat merupakan aplikasi yang dirancang untuk menggantikan fungsi HT pada smartphone android. Dimana selain dapat melakukan panggilan dengan suara, aplikasi ini juga dapat digunakan untuk melakukan komunikasi dengan text. Untuk melakukan komunikasi, aplikasi ini tidak memerlukan jaringan seluler[1], cukup dengan tersambung pada jaringan yang disediakan oleh access point yang sudah ada. Karena penggunaan jaringan seluler dibutuhkan adanya server sedangkan untuk penggunaan access point tidak memerlukan server[2]. Agar aplikasi dapat digunakan tanpa menggunakan jaringan seluler[3], maka pada saat pembuatan aplikasi memerlukan adanya socket.

Socket merupakan komponen/API (Application Programming) yang ada pada software android studio[4][5]. Sedangkan socket programming merupakan cara untuk menggunakan komponen/API socket untuk membuat sebuah aplikasi salah satunya aplikasi voice chat. Agar suatu socket dapat berkomunikasi dengan socket lainnya, maka socket butuh diberi suatu alamat unik berupa Alamat IP dan Nomer Port sebagai identifikasi[6][7]. Dengan menggunakan socket programming maka dapat dilakukan pertukaran informasi tanpa menggunakan jaringan seluler dan jangkauan untuk 
berkomunikasi tidak terbatas selama terhubung pada access point.

Aplikasi yang sudah dibuat nantinya akan diisntall pada beberapa smartphone android. Setelah terinstall, masingmasing smartphone dihubungkan pada jaringan yang disediakan oleh access point yang sudah ada agar dapat melakukan komunikasi dengan suara maupun teks. Komunikasi yang dilakuakan antar smartphone satu dengan yang lainnya secara point to point. Dilakukan pula pengukuran kualitas jaringan, yaitu QoS (Quality of Service).

Quality of Service (QoS) adalah kemampuan suatu elemen jaringan, seperti aplikasi jaringan, host, atau router untuk memiliki tingkatan jaminan bahwa elemen jaringan tersebut dapat memenuhi kebutuhan suatu layanan[8][9]. Terdapat beberapa parameter Quality of Service (QoS), yaitu sebagai berikut:

\section{Bandwidth}

Bandwidth adalah luas atau lebar cakupan frekuensi yang digunakan oleh sinyal dalam medium transmisi.

\section{Throughput}

Throughput adalah kemampuan sebenarnya suatu jaringan dalam melakukan pengiriman data. Biasanya throughput selalu dikaitkan dengan bandwidth dalam kondisi yang sebenarnya. Throughput dirumuskan pada persamaan (1).

$$
\text { Throughput }=\frac{\text { Packet received }(\mathrm{kb})}{\text { Time transmitted }(\mathrm{s})}
$$

Adapun standar Throughput menurut TIPHON ditunjukkan pada Tabel I.

TABEL I

STANDAR THROUGHPUT MENURUT TIPHON

\begin{tabular}{ccc}
\hline $\begin{array}{c}\text { Kategori } \\
\text { Throughput }\end{array}$ & Throughput & Indeks \\
\hline Bad & $0-338 \mathrm{kbps}$ & 0 \\
Poor & $338-700 \mathrm{kbps}$ & 1 \\
Fair & $700-1200 \mathrm{kbps}$ & 2 \\
Good & $1200 \mathrm{kbps}-2,1 \mathrm{Mbps}$ & 3 \\
Excelent & $>2,1 \mathrm{Mbps}$ & 4 \\
\hline
\end{tabular}

\section{Jitter}

Jitter adalah variasi atau perubahan latency dari delay atau variasi waktu kedatangan paket. Jitter juga didefinisikan sebagai gangguan pada komunikasi digital maupun analog yang disebabkan oleh perubahan sinyal karena referensi posisi waktu. Adapun standar jitter menurut TIPHON ditunjukkan pada Tabel II.

TABEL II

STANDAR JITTER MENURUT TIPHON

\begin{tabular}{ccc}
\hline Kategori Jitter & Jitter & Indeks \\
\hline Poor & $125-225 \mathrm{~ms}$ & 1 \\
Medium & $75-125 \mathrm{~ms}$ & 2 \\
Good & $0-75 \mathrm{~ms}$ & 3 \\
Perfect & $0 \mathrm{~ms}$ & 4 \\
\hline
\end{tabular}

\section{Packet Loss}

Packet loss adalah parameter yang menggambarkan suatu kondisi yang menunjukkan jumlah total paket yang hilang. Paket yang hilang ini dapat terjadi karena collision dan congestion pada jaringan. Packet Loss dihitung berdasarkan persentase paket yang berhasil dikirim, dirumuskan pada persamaan (2).

$$
\text { Packet Loss }=\frac{\text { Packet transmitted-Packet Received }}{\text { Time transmitted }} \times 100 \%
$$

Adapun standar packet loss menurut TIPHON ditunjukkan pada Tabel III.

TABEL III

STANDAR PACKET LOSS MENURUT TIPHON

\begin{tabular}{ccc}
\hline Kategori Jitter & Jitter & Indeks \\
\hline Poor & $>25 \%$ & 1 \\
Medium & $12-24 \%$ & 2 \\
Good & $3-14 \%$ & 3 \\
Perfect & $0-2 \%$ & 4 \\
\hline
\end{tabular}

\section{Latency}

Latency adalah total waktu tunda suatu paket yang diakibatkan oleh proses transmisi dari satu titik ke titik lain yang menjadi tujuannya. Delay di dalam jaringan terdiri dari delay processing, delay packetization, delay serialization, delay jitter buffer dan delay network. Adapun standar latency menurut TIPHON ditunjukkan pada Tabel IV.

TABEL IV

\begin{tabular}{ccc}
\multicolumn{3}{c}{ STANDAR LATENCY MENURUT TIPHON } \\
\hline Kategori & Latency & Indeks \\
Latency & $>450 \mathrm{~s}$ & 1 \\
Poor & $300-450 \mathrm{~s}$ & 2 \\
Medium & $150-300 \mathrm{~s}$ & 3 \\
Good & $<150 \mathrm{~s}$ & 4 \\
Perfect & &
\end{tabular}

\section{A. Blok Diagram Sistem}

\section{METODE PENELITIAN}

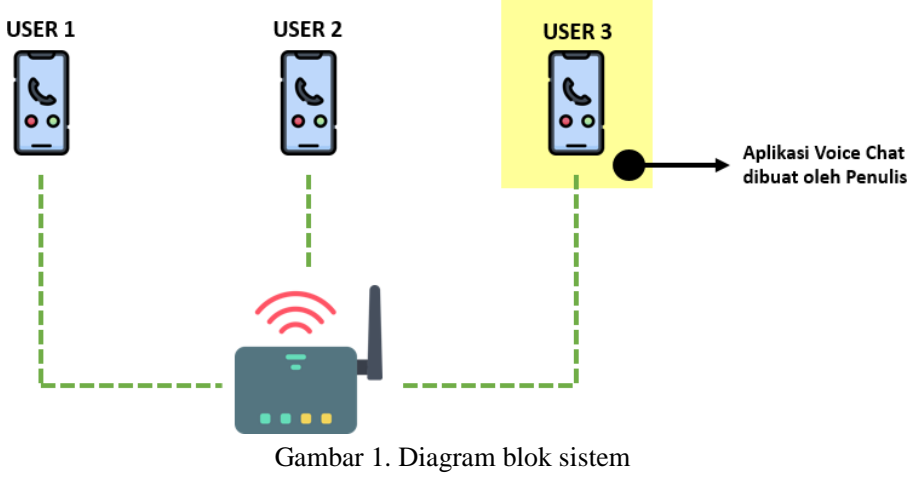

Pada Gambar 1 ditunjukkan blok diagram perancangan sistem diatas akan dijelaskan mengenai alur yang dilakukan selama penelitian, diantaranya sebagai berikut:

Melakukan instalasi aplikasi voice chat pada masing masing handphone user. Selanjutnya user menghubungkan smartphone ke jaringan lokal yang sudah tersedia (user terhubung melalui Access point) agar dapat menjalankan aplikasi voice chat. Handphone yang sudah sudah terhubung ke jaringan lokal maka dapat menjalankan aplikasi yang sudah dibuat untuk melakukan komunikasi. User mengirimkan data ke user lain berupa voice chat dan pesan 
text secara point-to- point untuk mendapatkan nilai data $Q o S$.

\section{B. Perancangan Aplikasi}

Aplikasi dirancang menggunakan software Android Studio. Dimana pada Android Studio terdapat API socket yang digunakan untuk merancang aplikasi. Layout perancangan aplikasi ditunjukkan pada Gambar 2.

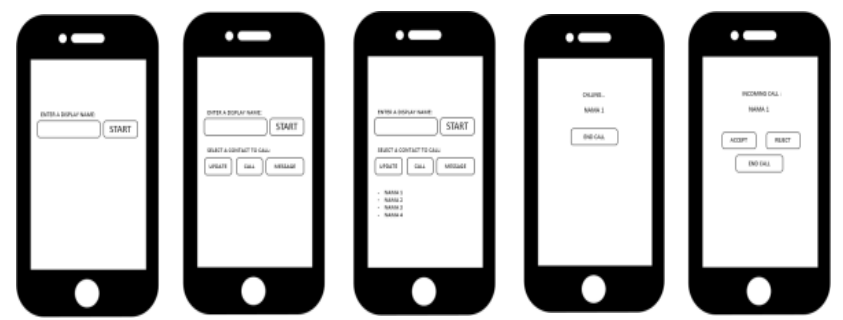

Gambar 2. Layout perancangan aplikasi

\section{Flowchart Alur Pengambilan Data}

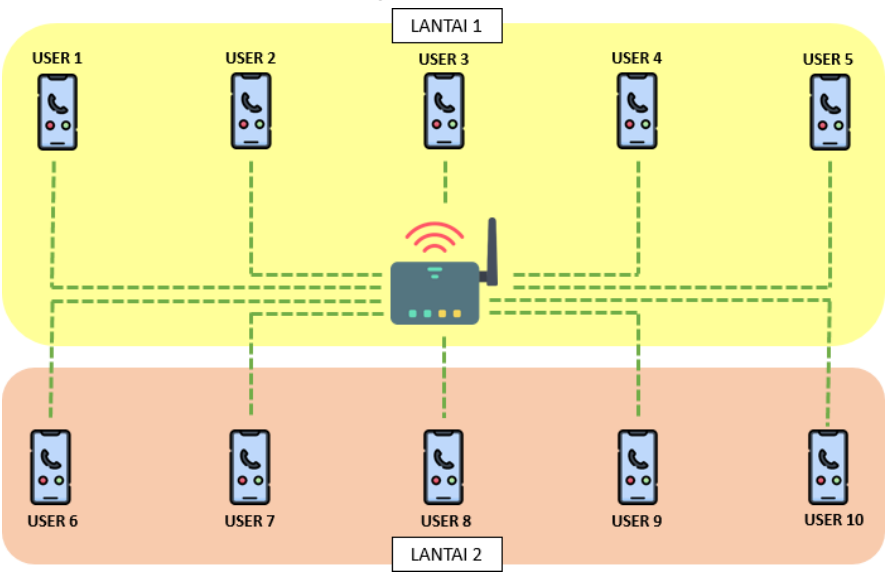

Gambar 3. Flowchart alur pengambilan data

Pada blok diagram alur pengambilan data akan dijelaskan mengenai alur yang dilakukan selama penelitian, diantaranya sebagai berikut:

Prosedur yang pertama yaitu meng-install aplikasi Voice Chat pada handphone masing - masing user. Proses instalasi selesai, selanjutntya masing-masing user menyambungkan handphone pada jaringan yang sudah ada (router). Setelah tersambung pada jaringan yang sama, maka masing-masing user dapat melakukan panggilan dengan suara maupun dengan text. User 1 akan melakukan panggilan pertama ke User 2, selanjutnya User 1 akan melakukan panggilan kedua pada User

3. User 1 akan melakukan panggilan pada setiap user secara bergantian. Begitu pula dengan User 2, User 3, User 4, User 5, User 6, User 7, User 8, User 9, dan User 10 akan melakukan panggilan pada setiap user lainnya. Pada setiap panggilan akan dihitung kualitas jaringannya yakni delay, throughput, dan packet loss.

\section{Prosedur Pengoperasian}

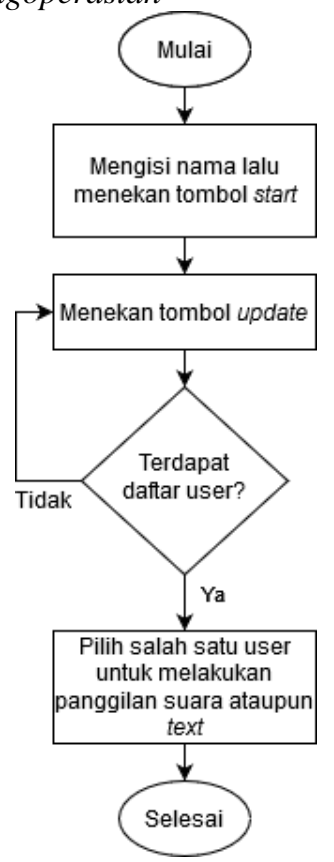

Gambar 4. Diagram Alir Prosedur Pengoperasian

Berdasarkan diagram alur prosedur pengoperasian dapat dijelaskan sebagai berikut: Pertama user harus masuk ke aplikasi yang telah dirancang, kemudian mengisi kolom nama yang sudah tersedia. Setelah user mengisikan nama selanjutnya user menekan tombol start agar nama yang dimasukkan dapat tersimpan. Selanjutnya user menekan tombol update agar dapat melihat daftar user lain yang sudah tersimpan. Nama yang sudah disimpan akan dibroadcast setiap satu menit sekali. Jika daftar user sudah tampil maka user akan memilih salah satu nama user lainnya untuk melakukan komunikasi. Untuk melakukan komunikasi dengan suara maka user menekan tombol call sedangkan untuk melakukan komunikasi dengan text maka user menekan tombol message.

\section{E. Parameter Penelitian}

Parameter penelitian ditentukan berdasarkan sistem yang telah dibuat dan digunakan sebagai parameter pengujian dalam sistem. Berikut parameter penelitian dalam perancangan yaitu: Keberhasilan instalasi aplikasi pada beberapa handphone dengan merk dan tipe yang berbeda; Kemampuan perangkat komunikasi untuk terhubung pada server; dan Kualitas jaringan saat melakukan komunikasi.

\section{HASIL DAN PEMBAHASAN}

A. Pengujian Tampilan Sebelum Melakukan Komunikasi 
TABEL V

HALAMAN UTAMA DAN DAFTAR USER

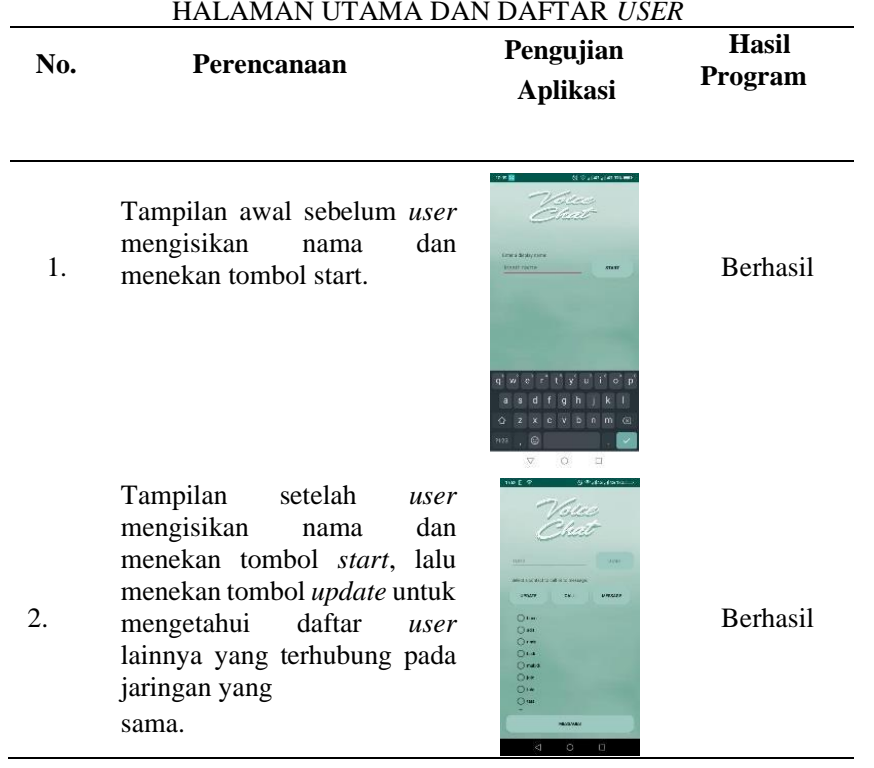

B. Pengujian Tampilan Saat Melakukan Kominkasi

TABEL VI

MELAKUKAN PANGGILAN DAN CHATTING

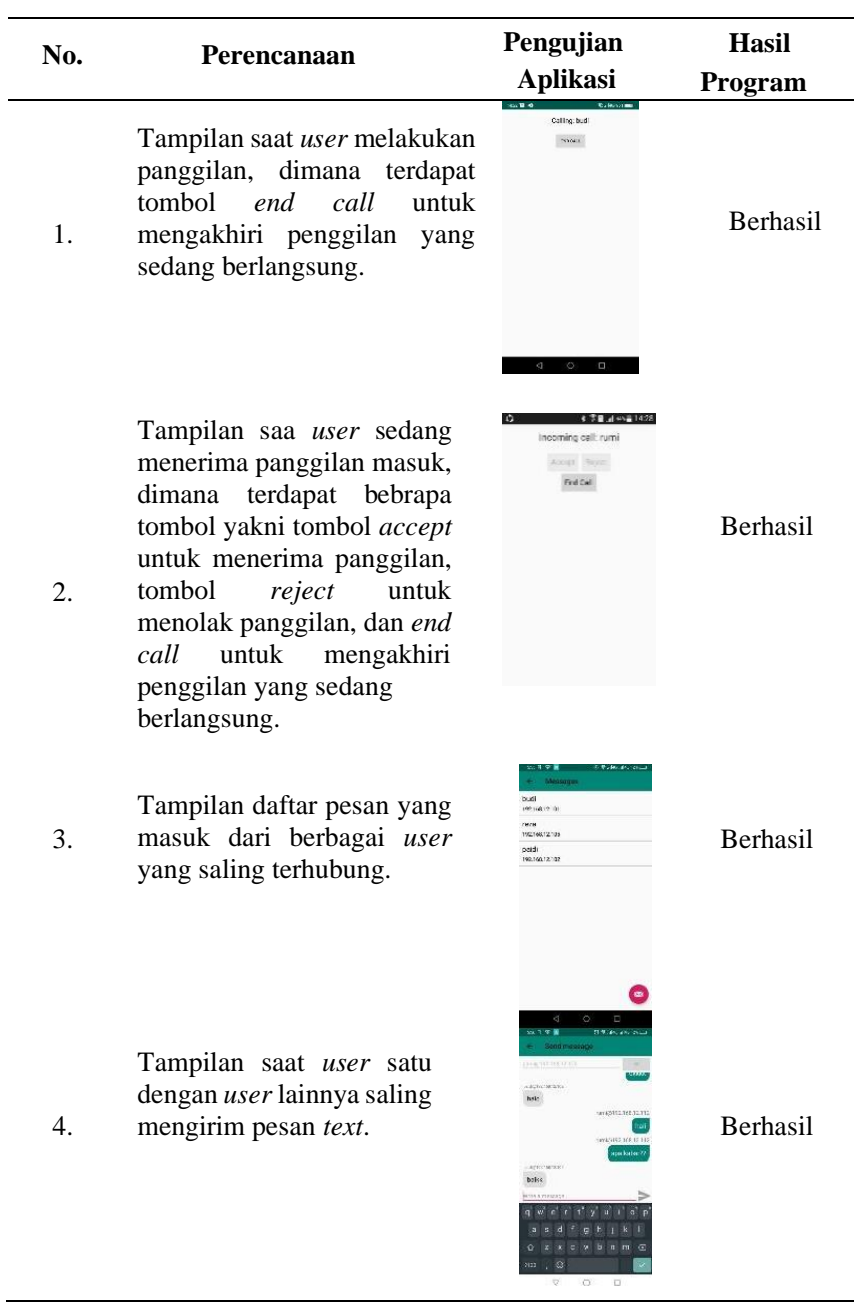

\section{Pengujian Komunikasi Dengan Suara}

TABEL VII

DAFTAR TIPE HANDPHONE DAN TITIK LOKASI

\begin{tabular}{cccc}
\hline No. & Nama & $\begin{array}{c}\text { Tipe } \\
\text { Handphone }\end{array}$ & Lokasi \\
\hline 1. & Rumi & Advan & Lt. 1 \\
2. & Reza & Asus & Lt. 1 \\
3. & Bono & Lenovo & Lt. 1 \\
4. & Adit & Samsung Prime & Lt. 1 \\
5. & Jojo & Redmi & Lt. 1 \\
6. & Rinda & Samsung & Lt. 2 \\
7. & Tata & Samsung & Lt. 2 \\
8. & Budi & Oppo & Lt. 2 \\
9. & Mukidi & Realme & Lt. 2 \\
10. & Tule & Samsung A8+ & Lt. 2 \\
\hline
\end{tabular}

Setelah melakukan pengujian didapatkan hasil dari 10 user yang menggunakan aplikasi yang telah dirancang diketahui bahwa tipe handphone juga mempengaruhi kecepatan penggunaan aplikasi pada saat menerima panggilan, karena setelah pengujian dari user Adit dan user Tule terdapat perbedaan kecepatan dimana mereka menggunakan merk handphone yang sama namun tipe handphone yang berbeda dan hasilnya aplikasi pada user Tule lebih cepat saat ada panggilan masuk daripada user Adit.

\section{Pengujian Komunikasi Dengan Text}

Setelah melakukan pengujian didapatkan hasil dari 10 user yang menggunakan aplikasi yang telah dirancang diketahui bahwa merk handphone juga mempengaruhi kinerja aplikasi pada saat chatting, karena setelah pengujian dari user Adit dan user Tule terdapat perbedaan kecepatan dimana mereka menggunakan merk handphone yang sama namun tipe handphone yang berbeda dan hasilnya aplikasi pada user Tule lebih cepat saat ada panggilan masuk daripada user Adit.

\section{E. Hasil Pengujian Komunikasi Pada Kondisi Berhasil}

1)Kualitas Komunikasi Rumi (192.168.12.112) : Untuk paket lossnya sama dengan 0 persen dikarenakan banyak data dikirim sama dengan data yang paling akhir pada proses. Sedang untuk throughputnya adalah 21250 Bytes perdetik. Untuk rata rata delay 20 proses awal pada hasil monitoring ada 2.2 detik. Bila dilihat pada tabel kategori delay termasuk jelek. Hal ini dikarenakan karena membutuhkan waktu untuk mencari jalur untuk sistem jaringan komunikasi dan melewati beberapa tahapan dalam prosesnya sehingga membutuhkan waktu lebih dari 1 detik.

2) Kualitas Komunikasi Reza (192.168.12.105) : Untuk paket lossnya sama dengan 0 persen dikarenakan banyak data dikirim sama dengan data yang paling akhir pada proses. Sedang untuk throughputnya adalah 21650 Bytes perdetik. Untuk rata rata delay 20 proses awal pada hasil monitoring ada 2 detik. Bila dilihat pada tabel kategori delay termasuk jelek. 
Hal ini dikarenakan karena membutuhkan waktu untuk mencari jalur untuk sistem jaringan komunikasi dan melewati beberapa tahapan dalam prosesnya sehingga membutuhkan waktu lebih dari 1 detik.

3) Kualitas Komunikasi Bono (192.168.12.108) : Untuk paket lossnya sama dengan 0 persen dikarenakan banyak data dikirim sama dengan data yang paling akhir pada proses. Sedang untuk throughputnya adalah 21750 Bytes perdetik. Untuk rata rata delay 20 proses awal pada hasil monitoring ada 2 detik. Bila dilihat pada tabel kategori delay termasuk jelek. Hal ini dikarenakan karena membutuhkan waktu untuk mencari jalur untuk sistem jaringan komunikasi dan melewati beberapa tahapan dalam prosesnya sehingga membutuhkan waktu lebih dari 1 detik.

4) Kualitas Komunikasi Adit (192.168.12.102): Untuk paket lossnya sama dengan 0 persen dikarenakan banyak data dikirim sama dengan data yang paling akhir pada proses. Sedang untuk throughputnya adalah 21550 Bytes perdetik. Untuk rata rata delay 20 proses awal pada hasil monitoring ada 2 detik. Bila dilihat pada tabel kategori delay termasuk jelek. Hal ini dikarenakan karena membutuhkan waktu untuk mencari jalur untuk sistem jaringan komunikasi dan melewati beberapa tahapan dalam prosesnya sehingga membutuhkan waktu lebih dari 1 detik.

5) Kualitas Komunikasi Jojo (192.168.12.113) : Untuk paket lossnya sama dengan 0 persen dikarenakan banyak data dikirim sama dengan data yang paling akhir pada proses. Sedang untuk throughputnya adalah 21550 Bytes perdetik. Untuk rata rata delay 20 proses awal pada hasil monitoring ada 2 detik. Bila dilihat pada tabel kategori delay termasuk jelek. Hal ini dikarenakan karena membutuhkan waktu untuk mencari jalur untuk sistem jaringan komunikasi dan melewati beberapa tahapan dalam prosesnya sehingga membutuhkan waktu lebih dari 1 detik.

6) Kualitas Komunikasi Rinda (192.168.12.106): Untuk rata rata delay 20 proses awal pada hasil monitoring ada 2 detik. Bila dilihat pada tabel kategori delay termasuk jelek. Hal ini dikarenakan karena membutuhkan waktu untuk mencari jalur untuk sistem jaringan komunikasi dan melewati beberapa tahapan dalam prosesnya sehingga membutuhkan waktu lebih dari 1 detik. untuk paket lossnya sama dengan 0 persen dikarenakan banyak data dikirim sama dengan data yang paling akhir pada proses. Sedang untuk throughputnya adalah 12852 Bytes perdetik.

7) Kualitas Komunikasi Rumi (192.168.12.110) : Untuk paket lossnya sama dengan 0 persen dikarenakan banyak data dikirim sama dengan data yang paling akhir pada proses. Sedang untuk throughputnya adalah 21100 Bytes perdetik. Untuk rata rata delay 20 proses awal pada hasil monitoring ada 2.1 detik. Bila dilihat pada tabel kategori delay termasuk jelek. Hal ini dikarenakan karena membutuhkan waktu untuk mencari jalur untuk sistem jaringan komunikasi dan melewati beberapa tahapan dalam prosesnya sehingga membutuhkan waktu lebih dari 1 detik.

\section{KESIMPULAN}

Aplikasi ini dapat digunakan untuk melakukan komunikasi dengan suara maupun text, selama user berada pada jaringan yang sama. Aplikasi ini dapat digunakan disegala jenis handphone Android untuk melakukan komunikasi dengan suara namun pada komunikasi dengan text hanya bisa digunakan pada merk handphone tertentu saja. Handphone yang tidak bisa digunakan untuk komunikasi dengan text ialah merk oppo dan realme. Pengujian kualitas jaringan pada saat melakukan komunikasi terbilang buruk pada parameter delay dan thgroughput dan unggul pada parameter packet loss. Rata-rata delay pada user sebesar 2.05 detik dan rata - rata throughput sebesar $20 \mathrm{kbps}$. Sedangkan tingkat keberhasilan pengiriman data sebesar $0 \%$.

[1] Kurose and Ross, Computer Networking: A top-down approach featuring the Internet, 3rd edition, Addison Wesley, 2004.

[2] Krismawardana, Y., Christyono, Y., \& Riyadi, M. A., "Perancangan dan Analisis Antena J-Pole Dualband Dengan Variasi Bentuk "T" Untuk Komunikasi Radio Transceiver Pada Pita VHF dan UHF'. Semarang: Universitas Diponegoro., 2015.

[3] Sofana, Iwan.. Teori dan Modul Praktikum Jaringan Komputer. Bandung: Modula, 2011.

[4] Tua Lesmana, Indra, Analisis Transfer Data Dengan Pemrograman Socket (Studi Kasus: Kendaraan Bergerak). Bandung: Politeknik Negeri Bandung, 2017.

[5] Selamet, Rachmat, Pemrograman Socket di Java. Bandung: Sekolah Tinggi Manajemen Informatika dan Komputer LIKMI, 2017.

[6] Amin, Miftakul. Implementasi Socket Programming dalam Pembuatan Sistem Antrian. Bandar Lampung: Informatics \& Business Institute Darmajaya, 2010.

[7] Fajar, Ahmad Nurul. Pemrograman Socket Dengan Java Dalam Mengembangkan Software Dengan Arsitektur Client Server. Jakarta: UIEU, 2006.

[8] Suhervan, Analisis Penerapan QOS (Quality Of Service) pada jaringan fram Relay Menggunakan Cisco Router. Jakarta: Universitas Esa Unggul, 2010.

[9] Wulandari, Rika, Analisis Qos (Quality Of Service) Pada Jaringan Internet (Studi Kasus : Upt Loka Uji Teknik Penambangan Jampang Kulon - Lipi). Sukabumi: UPT Loka Uji Teknik Penambangan Jampang Kulon Lembaga Ilmu Pengetahuan Indonesia, 2016. 